\begin{tabular}{|l|l|l|l|l|}
\hline Cuadernos de Investigación Geográfica & 2002 & $\mathbf{N}^{\circ} 28$ & pp. 31-47 & ISSN 0211-6820 \\
\hline
\end{tabular}

(C) Universidad de La Rioja

\title{
HEAVY METALAND AS TRANSPORT UNDER LOW AND HIGH FLOWS IN THE RIVER GUADIAMAR THREE YEARS AFTER THE AZNALCÓLLAR TAILINGS DAM FAILURE: IMPLICATIONS FOR RIVER RECOVERY AND MANAGEMENT
}

\author{
J. N. TURNER (1) \\ P.A. BREWER ${ }^{(1)}$ \\ M. G. MACKLIN (1) \\ K. A. HUDSON-EDWARDS ${ }^{(2)}$ \\ T. J. COULTHARD ${ }^{(1)}$ \\ A. J. HOWARD ${ }^{(3)}$ \\ H. E. JAMIESON (4)
}

(1) Institute of Geography and Earth Sciences, University of Wales,Aberystwyth, Wales SY23 3DB, UK

(2) School of Earth Sciences, Birkbeck College, University of London, Malet Street, London WC1E 7HX, UK

(3) School of Geography, University of Leeds, Leeds LS2 9JT, UK

(4) Department of Geological Sciences, Queen's University. Kingston, Ontario, K7L3N6, Canada

ABSTRACT: This paper presents work from an on-going research pro gramme examining the recovery of the Guadiamar River following the April 1998 Aznalcóllar tailings dam failure. Analysis of heavy metal (Cd, $\mathrm{Cu}, \mathrm{Pb}$ and $\mathrm{Zn}$ ) and $\mathrm{As}$ in surface waters, valley floor alluvium, overbank and suspended sediments are compared between six study reaches downs tream of the dam, over five sampling periods. The principal aims of the paper are to examine the distribution of contaminants in sediments and river waters and their delivery downstream under low and high flows, and the implications for river channel recovery and management three years after the tailings dam failure.

Results from a survey of Guadiamar alluvium carried out in January 1999 showed that, although clean-up operations were largely successful in restoring the affected area to pre-spill conditions, sediments continued to exceed intervention thresholds for the region. Residual contaminant levels were highest near the spill source, with isolated 'hotspots'of elevated con tamination throughout the affected area, superimposed on a general downstream decline in concentrations. In terms of contaminant mobility, surface water samples taken in May 99, under very low flows, have dis solved $C d, C u$ and $Z n$ concentrations which fail EC directive thresholds for surface water abstraction. Element concentrations are significantly lower for waters in January 1999, when controlled discharge from the Agrio reservoir was taking place. Under high flow conditions, sediment-associa - 
J.N. Turner, P.A. Brewer, M.G. Macklin, K.A. Hudson-Edwards,

T. J. Coulthard, A.J. Howard \& H.E. Jamieson

ted contaminant transport is dominant for all elements discussed, accoun ting for between $91 \%(\mathrm{Cu})$ and $99 \%(\mathrm{~Pb})$ of export yields. This has lead to the remobilisation of significant quantities of contaminants, particularly $\mathrm{Pb}$ and $\mathrm{Zn}$, during post-spill floods. Overbank deposits, however, show a fall in contaminant concentrations, following successive flood events. This has been due to sediment mixing of contaminated and "clean" material. Dilution has so far maintained contaminant concentrations below inter vention threshold limits in the lower reaches, thereby offering a cautiously optimistic prognosis for the sensitive wetlands of Doñana.

RESUMEN: Este trabajo estudia la recuperación del río Guardiamar después de la ruptura de una presa en Aznalcóllar en abril de 1998. Se han realizado análisis de metales pesados $(\mathrm{Cd}, \mathrm{Cu}, \mathrm{Pb}$ y $\mathrm{Zn})$ y arsénico en las aguas superficiales y llanura aluvial, y sedimento en suspensión en seis tramos aguas abajo de la presa, durante cinco periodos de muestreo. Los principales objetivos del estudio son examinar la distribución de contami nantes en los sedimentos y en las aguas fluviales, y su liberación aguas abajo con caudales bajos y altos, así como las implicaciones para la recuperación y gestión del cauce tres años después de la ruptura de la presa.

Los resultados obtenidos en el río Guardiamar en enero de 1999 demuestran que, aunque las operaciones de limpieza han tenido mucho éxito en la recuperación del área afectada, los sedimentos están por enci ma de los umbrales admisibles. Los niveles de contaminación residual fue ron más elevados cerca de la presa, con áreas aisladas de contaminación elevada a lo largo del cauce superponiéndose a una tendencia decrecien te aguas abajo. En términos de movilidad de contaminantes, los muestre os en agua superficial en mayo de 1999, con caudal muy bajo, tienen concentraciones de $\mathrm{Cd}$, $\mathrm{Cu}$ y $\mathrm{Zn}$ disueltos que no cumplen con la directiva de la Unión Europea. La concentración de elementos es significativamente menor en enero de 1999, cuando se soltó agua desde el embalse de Agrio. Con caudal elevado el transporte de contaminantes representa el 91 de $\mathrm{Cu}$, el $99 \%$ de $\mathrm{Pb}$, lo que conduce a la removilización de grandes cantidades de contaminantes, particularmente $\mathrm{Pb}$ y $\mathrm{Zn}$. La sedimentación en la llanura aluvial muestra un descenso en la concentración de contaminan tes después de sucesivas avenidas. La dilución ha mantenido la concentración de contaminantes por debajo de los límites de umbral en el curso bajo, lo que ofrece una perspectiva moderadamente optimista para las áreas húmedas de Doñana.

Key-words: Dam failure, Contamination, Heavy metals, Sediments, Wetlands, Andalucia, Spain.

Palabras clave: Ruptura de presa, Contaminación, Metales pesados, Sedimentos, Humedales, Andalucía, España.

\section{Introduction}

More than three years have passed since the Aznalcóllar tailings dam failure and the flooding of the Agrio-Guadiamar River in April 1998. Over this period major clean-up operations have been carried out on the channel, floodplain and valley floor. Studies undertaken shortly after the tailings dam failure emphasised the high toxicity of the heavy metal-bearing residues and the persistent threat these contaminants pose to the natural environment (Grimalt and Macpherson, 1999). However, little work has been pre- 
sented relating to the geomorphological and geochemical recovery of the river in the post-clean-up period (but see Macklin et al., 1999 and Benito et al., 2001). This paper presents water and sediment quality data which show how the Guadiamar is recovering both physically and chemically. Heavy metal $(\mathrm{Cd}, \mathrm{Cu}, \mathrm{Pb}$ and $\mathrm{Zn})$ and As levels in river water are presented for low and high flows, as well as for suspended and overbank sediment to assess the medium to long-term fate of these contaminants and the risks they pose to the environmentally sensitive lower reaches of the Doñana nature reserve.

\section{The Guadiamar basin: physiography, geology and mining}

The Guadiamar catchment is located in the Province of Sevilla, southern Spain (Figure 1) and drains an area of $1,879 \mathrm{~km}^{2}$. The river rises in the Ossa-Morena Zone, $24 \mathrm{~km}$ to the north of the town of Aznalcóllar and flows for $78 \mathrm{~km}$ until it joins the River Guadalquivir via the Brazo de la Torre. The climate in the region is typically Mediterranean, characterised by very dry summers and intermittent autumn-winter rains. The mean annual precipitation varies within the catchment between $800 \mathrm{~mm}$ in the headwaters to $500 \mathrm{~mm}$ downstream (CMA, 1999). Rainfall is often very intense, and the mean annual rainfall can be concentrated in a few torrential storms. As a consequence, the hydrological regime is characterised by low flows with infrequent flood events (Gallart et al., 1999; CHG,

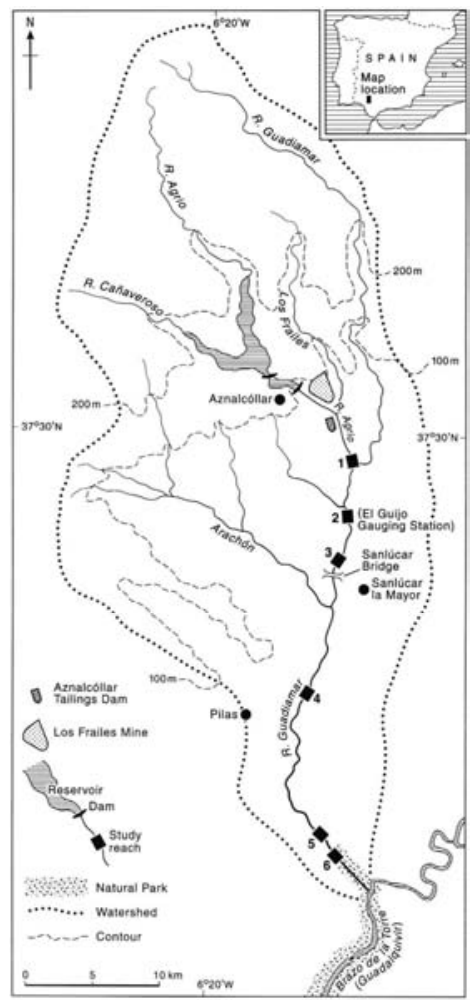

Figure 1. The Guadiamar catchment, showing the location of the six study reaches (after Macklin et al., 1999) 
J.N. Turner, P.A. Brewer, M.G. Macklin, K.A. Hudson-Edwards,

T. J. Coulthard, A.J. Howard \& H.E. Jamieson

1999). The northern part of the basin is underlain by Upper Devonian - Lower Carboniferous Volcano-Sedimentary Complex (Almodóvar et al., 1998). These are associated with the Iberian Pyrite Belt (IPB), formed of massive sulphide deposits which have long been exploited for base and precious metals. The southern part of the basin is underlain by Miocene silts and calcerenites, which are overlain by Eocene marl beds and Late-Quaternary sands and gravels. Early mining activity in the Aznalcóllar region dates back over 4 millennia and reached a peak during the Roman period (Boliden-Apirsa, 1999). The present phase of mining began in 1979 at Aznalcóllar, first by Andaluza de Piritas SA (Apirsa) and then by Boliden, who acquired Apirsa in 1987. The Aznalcóllar reserves were exhausted in 1996 and operations were transferred to the adjacent Los Frailes deposit in February 1997 (McDermott and Sibley, 2000). The tailings facility, that was breached in April 1998, was constructed in 1978 and was used for sub-aqueous storage of mine wastes (Sassoon, 1998). Land-use in the lower Guadiamar valley before the spill was dominated by agriculture. According to the Spanish authorities, the initial losses in production exceeded $\$ 10$ million (CMA, 1999). Along with providing an important water source for irrigation of agricultural land, the Guadiamar delivers fresh water to the wetlands of the Doñana nature reserve on the Atlantic coast. This region comprises several distinct and fragile ecosystems and provides refuge to more than $70 \%$ of European bird species (Grimalt et al., 1999). It is largely the threat of contamination to this unique national heritage that has driven the rehabilitation programmes.

\section{The tailings dam failiure}

The breach in the Aznalcóllar tailings dam at Boliden-Apirsa's Aznalcóllar/Los Frailes $\mathrm{Zn}-\mathrm{Pb}-\mathrm{Cu}$ mine occurred on the 25 April 1998. An estimated 5.5 million $\mathrm{m}^{3}$ of acidic water and 1.98 million $\mathrm{m}^{3}$ of pyritic tailings were discharged into the Agrio River (CMA, 1999), $2 \mathrm{~km}$ upstream of its confluence with the Guadiamar. According to UN statistics, this was the second largest mine spillage to have occurred worldwide in the last decade (WISE, 2001) and was by far the worst environmental pollution disaster recorded in Spanish history (Grimalt et al., 1999). Approximately 4600 ha along both sides of the river was flooded, with 2616 ha directly affected by tailings. More than $60 \%$ of the solid wastes were deposited in the first $13 \mathrm{~km}$ downstream of the breach, reaching depths of $4 \mathrm{~m}$ close to the impoundment and a few mm at the spill margins (CMA, 1999; LópezPamo et al., 1999; Eriksson and Adamek, 2000; McDermott and Sibley, 2000). The residues were largely composed of pyrite $(>80 \%)$ and other sulphide minerals, and contained $\mathrm{Pb}(0.8-1.1 \%)$; $\mathrm{Zn}(0.5-0.8 \%)$; As $(0.2-0.5 \%)$ and $\mathrm{Cu}(0.1-0.2 \%)$, with smaller proportions (<0.1\%) of Sb, Co, Tl, Cd Ag, Hg and Se (Simón et al., 1999).

\section{The clean-up operations}

Clean-up operations began on 3 May 1998, under the auspices of Boliden-Apirsa, the Confederación Hidrográfica del Guadalquivir (CHG) and the Consejería de Medio Ambiente (CMA). Work was undertaken in two phases, with all contaminated material transported to the former Aznalcóllar open pit for sub-aqueous storage. The first phase, 
completed in December 1998, was carried out without any consideration for metal concentrations in the soil (Eriksson and Adamek, 2000). During this phase, most of the deposited tailings and approximately 4.7 million $\mathrm{m}^{3}$ of contaminated soil were removed. The second phase was carried out during the summer of 1999 and targeted areas where residual contaminant concentrations exceeded intervention criteria for the region laid down in the Law of Wastes 10/1998 (González-Aurioles, 1999). A further 200 ha, confined mostly to the river channel and areas around upstanding trees, were cleaned and an additional 1 million $\mathrm{m}^{3}$ of material was removed (Eriksson and Adamek, 2000).

With such vast quantities of soil and sediment removed during the clean-up, the impacts on the river channel and valley floor morphology were considerable. Channelisation, involving dredging, re-sectioning and realignment of the river, was undertaken from the dam downstream to reach 6 (Figure 1), and all in-channel and most riparian vegetation (in the upper reaches) was removed. Channel banks and valley floor soils and sediments were left extremely vulnerable to erosion, increasing the risk of channel instability and the remobilisation of residual contaminants.

\section{Methodology}

In comparison to other research on the Agrio-Guadiamar this study in unique by providing an integrated geomorphological-geochemical approach to the assessment of river channel recovery. The scientific basis for this approach is that the deposition and storage patterns of sediment-associated contaminants can be related to floodplain geomorphology and river regimes in a predictable way (Lewin and Macklin, 1987; Graf, 1994; Macklin, 1996).

\subsection{Geomorphological mapping}

In January 1999 six study reaches were selected, representative of the principal river channel and floodplain environments affected by the spill (Table 1). At each reach a total station survey was carried out to establish a monumented local coordinate system and a detailed geomorphological map of channel and valley floor topography. Five further surveys have been carried out following flood events and/or further management intervention (Table 1). All topographical information has been geo-referenced and is stored in an Arc/Info ${ }^{\text {TM }}$ GIS.

\subsection{Sediment analysis}

Physical and chemical data for three types of sediment were collected:

1. valley floor alluvium was collected from each study reach to establish heavy metal and As concentrations in the Guadiamar following the clean-up;

2. suspended sediments sampled at reach 2 (El Guijo gauging station) during a flood in October 1999 and;

3. overbank sediments deposited during post-spill flood events. 
J.N. Turner, P.A. Brewer, M.G. Macklin, K.A. Hudson-Edwards,

T. J. Coulthard, A.J. Howard \& H.E. Jamieson

Table 1. Description and location of study reaches (after Macklin et al., 1999)

\begin{tabular}{|c|c|c|c|c|c|}
\hline Reach & $\begin{array}{l}\text { Location } \\
\text { (Lat, Long) }\end{array}$ & $\begin{array}{l}\text { Length } \\
(m)\end{array}$ & $\begin{array}{c}\text { Distance } \\
\text { downstream } \\
\text { from the mine } \\
\qquad(\mathrm{km})\end{array}$ & Survey dates & $\begin{array}{l}\text { Channel type } \\
\text { and } \\
\text { environment }\end{array}$ \\
\hline 1 & $\begin{array}{l}\text { River Agrio-River } \\
\text { Guadiamar } \\
\text { confluence } \\
\left(37^{\circ} 28^{\prime} \mathrm{N}, 6^{\circ} 13^{\prime} \mathrm{W}\right)\end{array}$ & 1300 & 2.5 & $\begin{array}{l}\text { Jan 1999; May 1999; } \\
\text { Oct 99; April 00; } \\
\text { Sept. 00; April 01 }\end{array}$ & $\begin{array}{l}\text { Active } \\
\text { wandering } \\
\text { gravel bed }\end{array}$ \\
\hline 2 & $\begin{array}{l}\text { El Guijo gauging } \\
\text { station } \\
\left(37^{\circ} 27^{\prime} \mathrm{N}, 6^{\circ} 13^{\prime} \mathrm{W}\right)\end{array}$ & 350 & 7.0 & $\begin{array}{l}\text { Jan 1999; May 1999; } \\
\text { Oct 99; Sept. 00; } \\
\text { April 01 }\end{array}$ & $\begin{array}{l}\text { Active low } \\
\text { sinuosity } \\
\text { gravel bed }\end{array}$ \\
\hline 3 & $\begin{array}{l}\text { Upstream of Sanlúcar } \\
\text { road bridge } \\
\left(37^{\circ} 24^{\prime} \mathrm{N}, 6^{\circ} 14^{\prime} \mathrm{W}\right)\end{array}$ & 340 & 11.3 & $\begin{array}{l}\text { Jan 1999; May 1999; } \\
\text { Oct 99; Sept. 00; } \\
\text { April } 01\end{array}$ & $\begin{array}{l}\text { Active low } \\
\text { sinuosity } \\
\text { gravel/sand } \\
\text { bed }\end{array}$ \\
\hline 4 & $\begin{array}{l}\text { Upstream of Aznalcázar } \\
\text { railway bridge } \\
\left(37^{\circ} 18.5^{\prime} \mathrm{N}, 6^{\circ} 15^{\prime} \mathrm{W}\right)\end{array}$ & 500 & 23.1 & $\begin{array}{l}\text { Jan } 1999 ; \text { May } 1999 ; \\
\text { Oct } 99 ; \text { Sept. 00; } \\
\text { April } 01\end{array}$ & $\begin{array}{l}\text { Stable low } \\
\text { sinuosity } \\
\text { sand/gravel } \\
\text { bed }\end{array}$ \\
\hline 5 & $\begin{array}{l}\text { La Tiésa } \\
\left(37^{\circ} 13.5^{\prime} \mathrm{N}, 6^{\circ} 14^{\prime} \mathrm{W}\right)\end{array}$ & 930 & 38.4 & $\begin{array}{l}\text { Jan 1999; May 1999; } \\
\text { Oct 99; Sept. 00; } \\
\text { April 01 }\end{array}$ & $\begin{array}{l}\text { Stable straight } \\
\text { silt/sand } \\
\text { bed (tidal) }\end{array}$ \\
\hline 6 & $\begin{array}{l}\text { Puente San Simone } \\
\left(37^{\circ} 11.5^{\prime} \mathrm{N}, 6^{\circ} 13^{\prime} \mathrm{W}\right)\end{array}$ & 640 & 43.5 & $\begin{array}{l}\text { Jan 1999; May 1999; } \\
\text { Oct 99; Sept. 00; } \\
\text { April } 01\end{array}$ & $\begin{array}{l}\text { Stable straight } \\
\text { silt/sand } \\
\text { bed (tidal) }\end{array}$ \\
\hline
\end{tabular}

All sediment sample sites have been spatially referenced and linked to the geomorphic maps of the channel, floodplain and valley floor.

Surface samples (100-200g) were collected over a c. $10 \mathrm{~m}^{2}$ area by combining 10 random surface sub-samples from a depth of $3-5 \mathrm{~cm}$. The sub-samples were homogenised and a disaggregated portion was air-dried, passed through a $2 \mathrm{~mm}$ screen and milled for four minutes. Samples were digested using either $\mathrm{HNO}_{3}-\mathrm{HF}-\mathrm{HCLO}_{4}$ (valley floor alluvium, February 1999 and October 1999 overbank sediments, October 1999 suspended sediments), or using concentrated (70\%) $\mathrm{HNO}_{3}$ (October 1999, March 2000, and May 2000 overbank sediments). A comparison between the two digestion methods shows a good correlation $\left(\mathrm{R}^{2}>0.9\right.$ at $95 \%$ significance level) for all elements reported. The $\mathrm{HNO}_{3}-\mathrm{HF}-$ $\mathrm{HCLO}_{4}$ procedure removed, on average, $5 \%$ less As, $5 \%$ less $\mathrm{Cd}, 20 \%$ more $\mathrm{Cu}, 15 \%$ more $\mathrm{Pb}$ and $10 \%$ less $\mathrm{Zn}$ than the $(70 \%) \mathrm{HNO}_{3}$ method. Analyses were carried out by ICP-MS (VG Elemental Plasma Quad II+) at the Institute of Geography and Earth Sciences (IGES), University of Wales, Aberystwyth. Analytical precision was determined by inserting blind duplicates to approximately $10 \%$ of the total number of samples analysed. Analytical accuracy was determined using Chinese reference standards for stream sediments (GSD5; GSD7; GSD12). Both precision and accuracy were within $10 \%$, except for Cd under very low concentrations $(<0.1 \mathrm{mg} / \mathrm{kg})$. 


\subsection{Water sampling and analysis}

River water samples were taken from the Guadiamar and the Agrio at reaches 1 to 5 in January 1999, May 1999 and October 1999. Samples were filtered in the field through $0.45 \mu \mathrm{m}$ cellulose nitrate screens and those destined for cation analysis were acidified with $2 \mathrm{ml}$ of concentrated $\mathrm{HNO}_{3}$. Analyses were carried out by ICP-MS at the Department of Geological Sciences, Queen's University Kingston, Canada and at IGES University of Wales, Aberystwyth. Analytical accuracy, measured with a reference water (SLRS-4) from the National Research Council of Canada and an in-house standard at IGES, Aberystwyth, was generally within $10 \%$. Analytical precision of field and laboratory duplicates was also generally within $10 \%$.

\section{Results}

\subsection{Post clean-up conditions in the affected area}

Table 2 summarises the January 1999 and May 1999 geochemical data and shows that, following the clean-up operations, the reaches closest to the failed tailings dam had the highest heavy metal and As concentrations. Although concentrations generally declined downstream, these were not uniform and contaminant concentrations increased between reach 1 to $2(\mathrm{Zn}, \mathrm{Cd})$, reach 2 to $3(\mathrm{Cu})$, reach 3 to $4(\mathrm{As}, \mathrm{Pb})$ and reach 5 to 6 $(\mathrm{Zn})$. There was also considerable spatial variability in contaminant concentration at all six reaches (Table 2). High heavy metal and As concentrations found in individual samples very often reflected the patchy distribution of residual tailings following the cleanup and even as recently as April 2001 raw tailings were still evident in several of the reaches. Given the long history of metal mining in the region, however, elevated levels may also reflect historic pollution prior to the spill. Hudson-Edwards et al. (in press) compared metal levels in studies undertaken during the modern mining era (post-1979) with pre-spill alluvium, and showed that mining activity during the 1980s and 1990s had already increased the contaminant loadings (González et al., 1990; Ramos et al., 1994; Martín et al., 2000). The January 1999 heavy metal and As levels were generally lower than those reported in the earlier studies, suggesting that the clean-up operations were effective in removing the majority of contaminated sediment released by the tailings dam failure. However, mean concentrations in post-spill alluvium still represent a quantifiable risk to human and ecosystem health. Intervention thresholds for the Guadiamar were drawn up in December 1998, following extensive sampling and analysis of catchment soils and sediments (González-Aurioles, 1999). These values are shown in Table 2, along with Dutch interventions limits that are generally more stringent. When compared to the non-sensitive intervention thresholds for non-agricultural landuse, heavy metal and As levels in the upper reaches continue to be remediation concern.

\subsection{Low flow water quality}

Dissolved heavy metal and As concentrations in Agrio-Guadiamar river water samples taken in January and May 1999 are summarised in Figure 2. Background element levels 
J.N. Turner, P.A. Brewer, M.G. Macklin, K.A. Hudson-Edwards,

T. J. Coulthard, A.J. Howard \& H.E. Jamieson

Table 2. Ranges and mean values $(\mathrm{mg} / \mathrm{kg})$ of sediment-associated heavy metal and As concentra tions for Guadiamar alluvium before and after the tailings dam failure (after Macklin et al., 1999 and Hudson et al., 2001, in press)

\begin{tabular}{|c|c|c|c|c|c|}
\hline Sample/area & As & $\mathrm{Cd}$ & $\mathrm{Cu}$ & $\mathrm{Pb}$ & $\mathrm{Zn}$ \\
\hline \multicolumn{6}{|c|}{ River Guadiamar post clean-up alluvium (Jan and May 99) } \\
\hline Reach $1(n=7)$ & $\begin{array}{c}320 \\
(20-1200)\end{array}$ & $\begin{array}{c}4.7 \\
(0.5-12)\end{array}$ & $\begin{array}{c}260 \\
(17-490)\end{array}$ & $\begin{array}{c}990 \\
(50-2700)\end{array}$ & $\begin{array}{c}1200 \\
(140-4600)\end{array}$ \\
\hline Reach $2(n=10)$ & $\begin{array}{c}320 \\
(40-860)\end{array}$ & $\begin{array}{c}5.5 \\
(0.9-11)\end{array}$ & $\begin{array}{c}190 \\
(50-340)\end{array}$ & $\begin{array}{c}680 \\
(98-1500)\end{array}$ & $\begin{array}{c}1600 \\
(330-3200)\end{array}$ \\
\hline Reach $3(n=13)$ & $\begin{array}{c}220 \\
(36-1000)\end{array}$ & $\begin{array}{c}4.1 \\
(0.6-9.3)\end{array}$ & $\begin{array}{c}310 \\
(110-730)\end{array}$ & $\begin{array}{c}610 \\
(110-2200)\end{array}$ & $\begin{array}{c}1200 \\
(270-3200)\end{array}$ \\
\hline Reach $4(n=13)$ & $\begin{array}{c}280 \\
(46-680)\end{array}$ & $\begin{array}{c}2.7 \\
(0.1-5.6)\end{array}$ & $\begin{array}{c}190 \\
(58-370)\end{array}$ & $\begin{array}{c}780 \\
(71-1600)\end{array}$ & $\begin{array}{c}900 \\
(270-1700)\end{array}$ \\
\hline Reach $5(n=11)$ & $\begin{array}{c}93 \\
(30-180)\end{array}$ & $\begin{array}{c}2.5 \\
(<0.1-6.9)\end{array}$ & $\begin{array}{c}150 \\
(28-300)\end{array}$ & $\begin{array}{c}300 \\
(66-750)\end{array}$ & $\begin{array}{c}670 \\
(190-1800)\end{array}$ \\
\hline Reach $6(n=9)$ & $\begin{array}{c}41 \\
(27-37)\end{array}$ & $\begin{array}{c}4.6 \\
(1.0-6.0) \\
\end{array}$ & $\begin{array}{c}88 \\
(45-110) \\
\end{array}$ & $\begin{array}{c}120 \\
(67-250) \\
\end{array}$ & $\begin{array}{c}1100 \\
(680-1400) \\
\end{array}$ \\
\hline \multicolumn{6}{|c|}{ Pre-spill alluvium and tailings } \\
\hline $\begin{array}{l}\text { Pre-spill } \\
\text { alluvium } \\
(n=17)\end{array}$ & $\begin{array}{c}39 \\
(13-110)\end{array}$ & $\begin{array}{c}0.1 \\
(0.1-2.6)\end{array}$ & $\begin{array}{c}78 \\
(9.6-280)\end{array}$ & $\begin{array}{c}140 \\
(18-540)\end{array}$ & $\begin{array}{c}220 \\
(70-900)\end{array}$ \\
\hline Tailings $(\mathrm{n}=11)$ & $\begin{array}{c}2500 \\
(1800-3700) \\
\end{array}$ & $\begin{array}{c}27 \\
(12-76) \\
\end{array}$ & $\begin{array}{c}1600 \\
(950-3000)\end{array}$ & $\begin{array}{c}8500 \\
(3700-12000) \\
\end{array}$ & $\begin{array}{c}7400 \\
(3700-23000) \\
\end{array}$ \\
\hline \multicolumn{6}{|c|}{ Results from former studies on the Guadiamar } \\
\hline $\begin{array}{l}\text { Alluvium }(1996)^{\mathrm{a}} \\
(\mathrm{n}=15) \\
\text { Alluvium }(1990)^{\mathrm{b}} \\
(\mathrm{n}=3) \\
\text { Alluvium }(1983)^{\mathrm{c}} \\
(\mathrm{n}=8)\end{array}$ & $\begin{array}{c}160 \\
\text { (s.d. } 400)\end{array}$ & $\begin{array}{c}\text { n.r. } \\
9.5 \\
(4.72-13.1) \\
6.1 \\
(0.7-10.0)\end{array}$ & $\begin{array}{c}760 \\
(\text { s.d. } 780) \\
649 \\
(90.4-1340) \\
556 \\
(24-1409) \\
\end{array}$ & $\begin{array}{c}280 \\
\text { (s.d. } 550) \\
76 \\
(35.4-126) \\
473 \\
(22-1212) \\
\end{array}$ & $\begin{array}{c}4670 \\
\text { (s.d. } 7110) \\
2690 \\
(948-4200) \\
2043 \\
(68-5204) \\
\end{array}$ \\
\hline \multicolumn{6}{|c|}{ Intervention threshold values assigned to the Guadiamar by the Spanish authorities ${ }^{d}$} \\
\hline $\begin{array}{l}\text { Sensitive } \\
\text { Non-sensitive }\end{array}$ & $\begin{array}{c}52 \\
100 \\
\end{array}$ & $\begin{array}{c}5 \\
10 \\
\end{array}$ & $\begin{array}{l}250 \\
500 \\
\end{array}$ & $\begin{array}{l}350 \\
500 \\
\end{array}$ & $\begin{array}{c}700 \\
1200 \\
\end{array}$ \\
\hline \multicolumn{6}{|c|}{ Dutch intervention thresholds ${ }^{e}$} \\
\hline $\begin{array}{l}\text { Target } \\
\text { Intervention }\end{array}$ & $\begin{array}{l}29 \\
55\end{array}$ & $\begin{array}{c}0.8 \\
12\end{array}$ & $\begin{array}{c}36 \\
190\end{array}$ & $\begin{array}{c}85 \\
530\end{array}$ & $\begin{array}{l}140 \\
720\end{array}$ \\
\hline
\end{tabular}

were established in the Guadiamar waters by sampling upstream and outside of the affected area in January 1999. The horizontal lines show European Union directive values for the abstraction of drinking water (75/440/EEC). The long-dashed lines denote imperative thresholds (As $50 \mu \mathrm{g} / \mathrm{l}$; Cd $5 \mu \mathrm{g} / \mathrm{l}$; Cu $50 \mu \mathrm{g} / \mathrm{l}$; Pb $50 \mu \mathrm{g} / \mathrm{l}$; Zn $3000 \mu \mathrm{g} / \mathrm{l}$ ) and the shortdashed lines denote guideline thresholds (As $10 \mu \mathrm{g} / \mathrm{l} ; \mathrm{Cd} 1 \mu \mathrm{g} / \mathrm{l} ; \mathrm{Cu} 20 \mu \mathrm{g} / \mathrm{l} ; \mathrm{Zn} 500 \mu \mathrm{g} / \mathrm{l}$ ).

In January 1999, water samples had higher pH values and lower dissolved concentrations for all elements measured, with the single exception of As in the Agrio at reach 1, than water samples collected in May 1999 (Hudson-Edwards et al., in press). This is believed to be due, in part, to the controlled discharge of water from the Agrio reservoir during January 1999 following an unseasonably dry winter. A second factor maintaining low concentrations in the January water samples is thought to be the reduced rates of sulphide oxidation and contaminant dissolution during the relatively cooler winter months. 

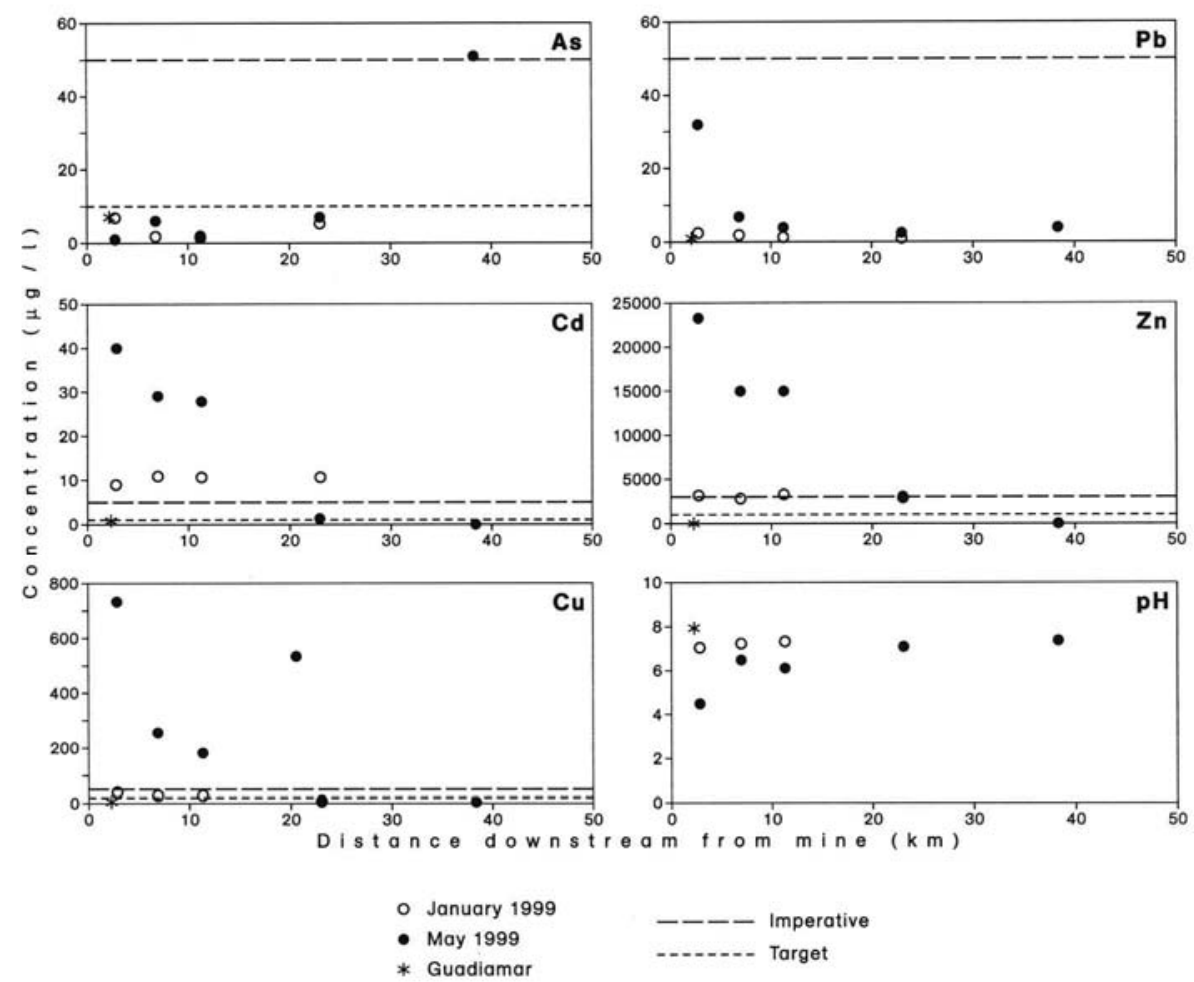

* Guadiamar

Figure 2. Downstream changes in dissolved heavy metal and As concentrations under low flows (data from Hudson-Edwards et al., in press)

Contaminant concentrations in May 1999 water samples decreased downstream from reach 1 to reach 5, and were probably related to a combination of precipitation/adsorption processes and dilution (Hudson-Edwards et al. , in press). The increase in As concentrations between reaches 4 and 5 is attributed to either differences in the anionic behaviour of $\mathrm{As}$ compared to $\mathrm{Cd}, \mathrm{Cu}, \mathrm{Pb}$ and $\mathrm{Zn}$ or to an alternative source of $\mathrm{As}$ (such as lead arsenate pesticides) in the catchment. In terms of EU directives, the May 1999 waters all exceeded imperative thresholds for $\mathrm{Cd}, \mathrm{Cu}$ and $\mathrm{Zn}$ in the upper three reaches, and for As at reach 5 .

It is possible to calculate a low flow dissolved contaminant yield in May 1999 waters at reach 2 (El Guijo gauging station) using a mean daily discharge of $1 \mathrm{~m}^{3} / \mathrm{s}$ (measured base flow; CHG, 1999) and element concentration data reported in Hudson-Edwards et al. (in press). Dissolved contaminant yields vary considerably between the elements described here: $\mathrm{As}(0.5 \mathrm{~kg} /$ day $), \mathrm{Cd}(2.5 \mathrm{~kg} /$ day $), \mathrm{Cu}(21.3 \mathrm{~kg} /$ day $) \mathrm{Pb}(0.5 \mathrm{~kg} /$ day $)$ and $\mathrm{Zn}(1,296 \mathrm{~kg} / \mathrm{day})$. Low flow water quality in the Guadiamar is still poor, especially for $\mathrm{Cd}, \mathrm{Cu}$ and $\mathrm{Zn}$. 
J.N. Turner, P.A. Brewer, M.G. Macklin, K.A. Hudson-Edwards,

T. J. Coulthard, A.J. Howard \& H.E. Jamieson

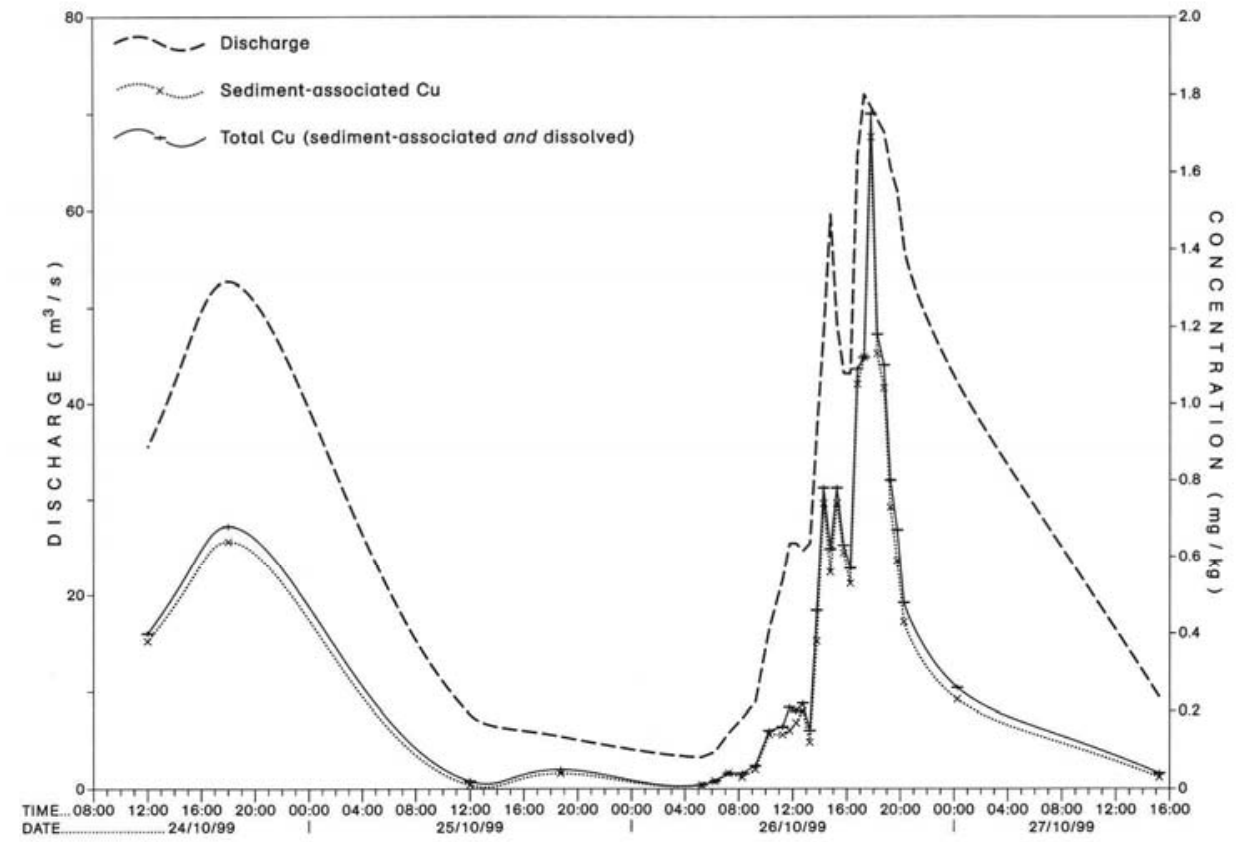

Figure 3. Cu export at El Guijo gauging station during the October 1999 flood

\subsection{High flow sediment and water quality}

Figure 3 shows total (sediment-associated and dissolved) and sediment-associated yields for $\mathrm{Cu}$ at El Guijo gauging station (Figure 1, reach 2) during the October 1999 flood. This was the first major flood $\left(>10 \mathrm{~m}^{3} / \mathrm{s}\right)$ in the Guadiamar River following the tailings dam failure. Sampling began at 12:00 hours on $24^{\text {th }}$ October and continued until 12:15 hours on the $27^{\text {th }}$ October. The graph shows a $\mathrm{Cu}$ yield pattern that closely reflects the flood hydrograph. In addition, the total and sediment-associated curves are almost coincident, illustrating the dominant role that suspended sediments play in transporting $\mathrm{Cu}$. The divergence of the total and sediment-associated curves, displayed on the waning limb of the second flood wave, is due to the effect of sediment exhaustion. This is illustrated by the positive hysteresis curve shown in Figure 4. Irregularities in the form of the curve in Figure 4 represent sediment pulses arriving during the flood.

Sediment-associated transport is equally important for $\mathrm{As}, \mathrm{Cd}, \mathrm{Pb}$ and $\mathrm{Zn}$, accounting for up to $99 \%$ of contaminants mobilised during the October 1999 flood (Table 3). Total sediment-associated loads indicate the remobilisation of significant quantities of $\mathrm{Zn}$ and $\mathrm{Pb}$ during the sampling period (Table 3). Almost 22,000 tonnes of suspended sediment passed through the El Guijo gauging station during the sampling period and there was a reduction in mean contaminant concentrations in the suspended sediments compared to those recorded in the baseline alluvium at reach 2 (Table 2 ) for all elements discussed: 


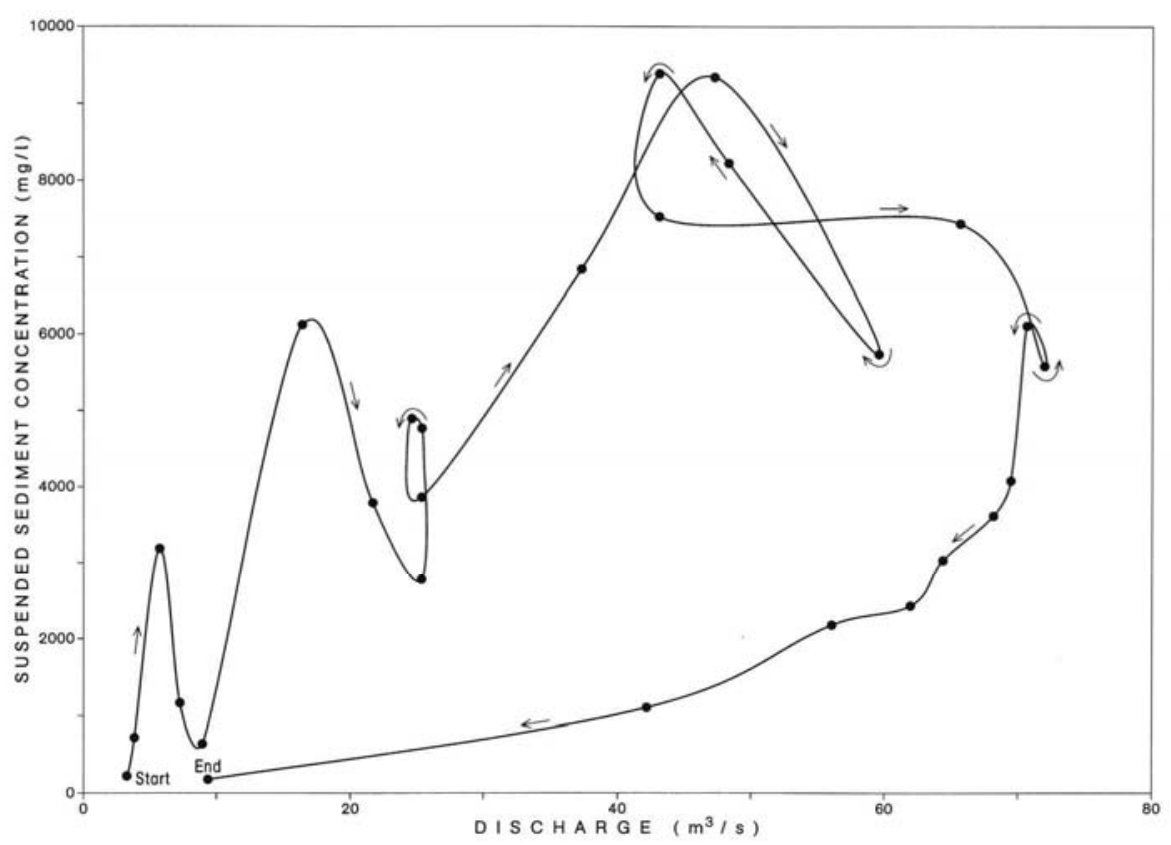

Figure 4. Suspended sediment hysteresis at El Guijo gauging station during the October 1999 flood

As (78\%), $\mathrm{Cd}(66 \%), \mathrm{Cu}(72 \%), \mathrm{Pb}(72 \%)$ and $\mathrm{Zn}(63 \%)$. Although the fall in contaminant concentrations could be due to the summer 1999 clean-up campaign, an alternative explanation could be the effect of contaminant dilution due to the mixing of contaminated and "clean" material. A statistical comparison of suspended sediment and $\mathrm{Zn}$ concentrations for part of the flood wave (when the influence of particle size is negligible) gives a significant inverse relationship at the $99 \%$ significance level. Figure 5 illustrates the effect of sediment mixing by showing how sediment pulses coincide with a fall in $\mathrm{Zn}$

Table 3. Sediment-associated and dissolved yields, and mean heavy metal and As concentrations during high flows: 24/10/99 to 27/10/99

\begin{tabular}{|c|c|c|c|c|c|c|}
\hline & $\begin{array}{c}\text { Sediment-associated } \\
\text { load }(\mathrm{kg})\end{array}$ & $\begin{array}{c}\text { Percentage } \\
\text { moving } \\
\text { with sediment }\end{array}$ & $\begin{array}{c}\text { Mean sediment- } \\
\text { associated } \\
\text { concentration } \\
(\text { mg/kg_ppm })\end{array}$ & $\begin{array}{c}\text { Dissolved } \\
\text { load }(\mathrm{kg})\end{array}$ & $\begin{array}{c}\text { Percentage } \\
\text { moving in } \\
\text { aqueous } \\
\text { solution }\end{array}$ & $\begin{array}{c}\text { Mean } \\
\text { dissolved } \\
\text { concentration } \\
\left(\mu g / l_{-} p p b\right)\end{array}$ \\
\hline $\mathrm{As}$ & 1500 & 97.9 & 71 & 33 & 2.1 & 3.3 \\
$\mathrm{Cd}$ & 41 & 97.6 & 1.9 & 1.1 & 2.4 & 0.2 \\
$\mathrm{Cu}$ & 1100 & 91.1 & 52 & 110 & 8.9 & 16 \\
$\mathrm{~Pb}$ & 4200 & 99.9 & 190 & 4.2 & 0.1 & 0.6 \\
$\mathrm{Zn}$ & 13000 & 98.5 & 600 & 190 & 1.5 & 27 \\
\hline
\end{tabular}


J.N. Turner, P.A. Brewer, M.G. Macklin, K.A. Hudson-Edwards,

T. J. Coulthard, A.J. Howard \& H.E. Jamieson

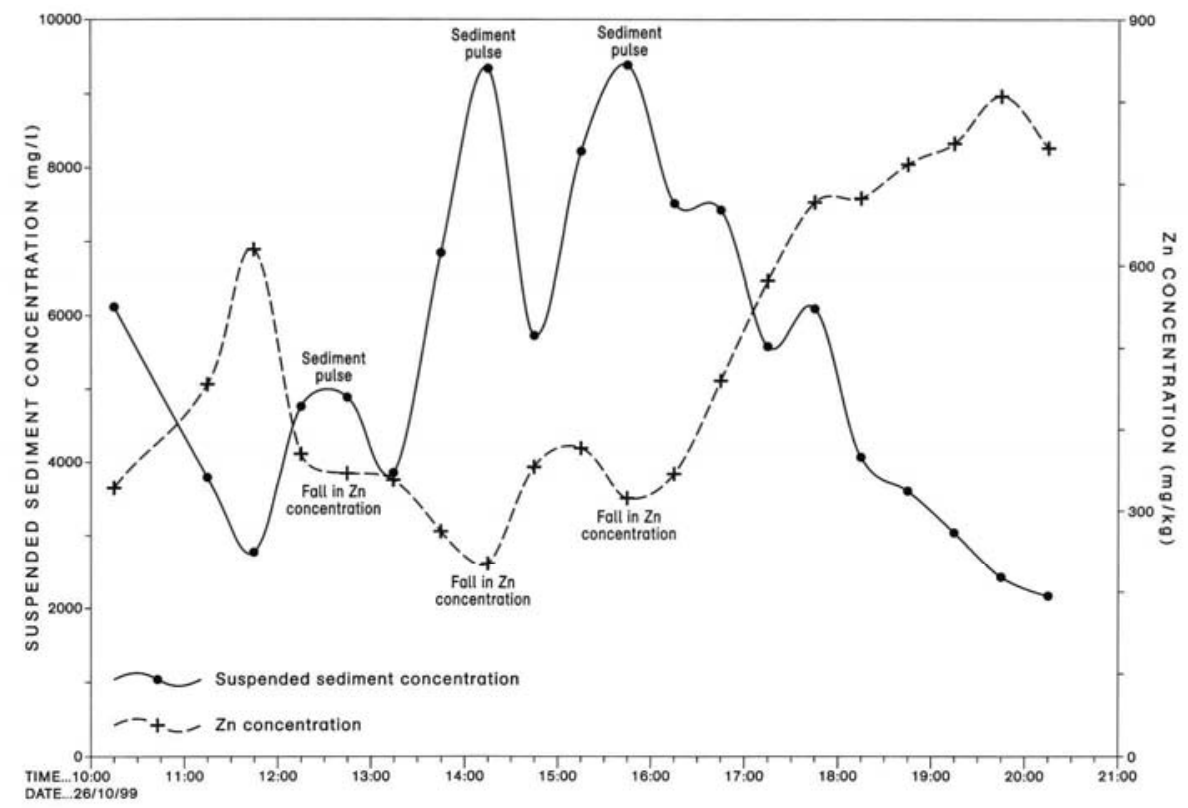

Figure 5. A comparison of suspended sediment and Zn concentrations at El Guijo gauging station, during the October 1999 flood.

concentration. As a result of dilution, although large quantities of contaminants were mobilised in this flood, the concentrations of heavy metals and As moving towards the sensitive lower reaches did not exceed non-sensitive threshold intervention values shown in Table 2.

In the October 1999 flood waters, dissolved contaminant concentrations are more than an order of magnitude lower than those recorded in May 1999 water samples, and all element concentrations lie within guideline values for water abstraction (Table 3). Although there are a number of factors that could control element solubility, including mineralogy and organic matter content, as the $\mathrm{pH}$ of the flood waters varied between $\mathrm{pH}$ 7.3 and $\mathrm{pH} 8.1$, alkaline conditions are likely to have impeded dissolution.

\subsection{Overbank sediment}

The longer term pattern of sediment-associated contaminant export can be evaluated by examining element concentrations in overbank sediment. Figure 6 shows heavy metal and As concentrations in overbank sediments sampled after flood events in March 1999 $\left(10 \mathrm{~m}^{3} / \mathrm{s}\right)$, October $1999(72 \mathrm{~m} 3 / \mathrm{s})$, April 2000 (no discharge information) and May 2000 $\left(75 \mathrm{~m}^{3} / \mathrm{s}\right)$. Heavy metal concentrations are given for mean, maximum and minimum values at reach 1 and for reaches 5 and 6. Data for reaches 5 and 6 were combined, as they are both located in the tidal, channelised section of the lower Guadiamar that borders the 
Heavy metal and as transport under low and high flows in the river Guadiamar three years after the Aznalcóllar tailings dam failure

Reach 1
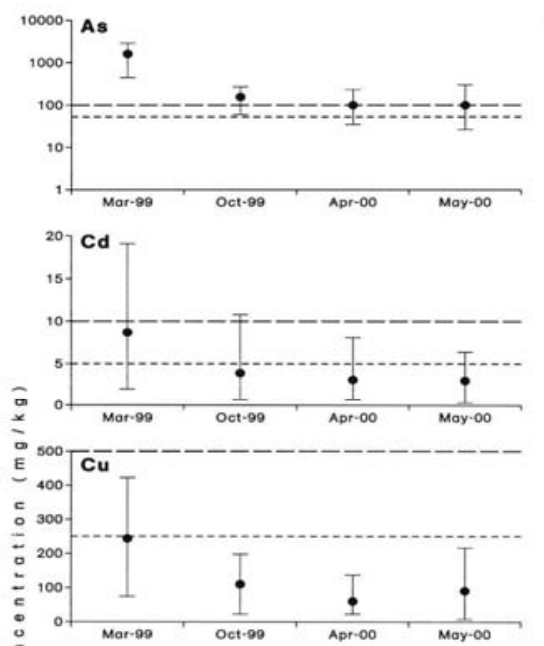

$: 1500$
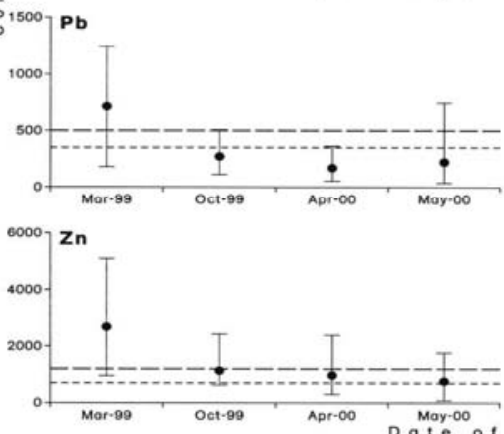

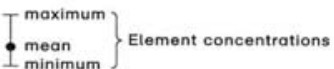

Reaches 5 and 6
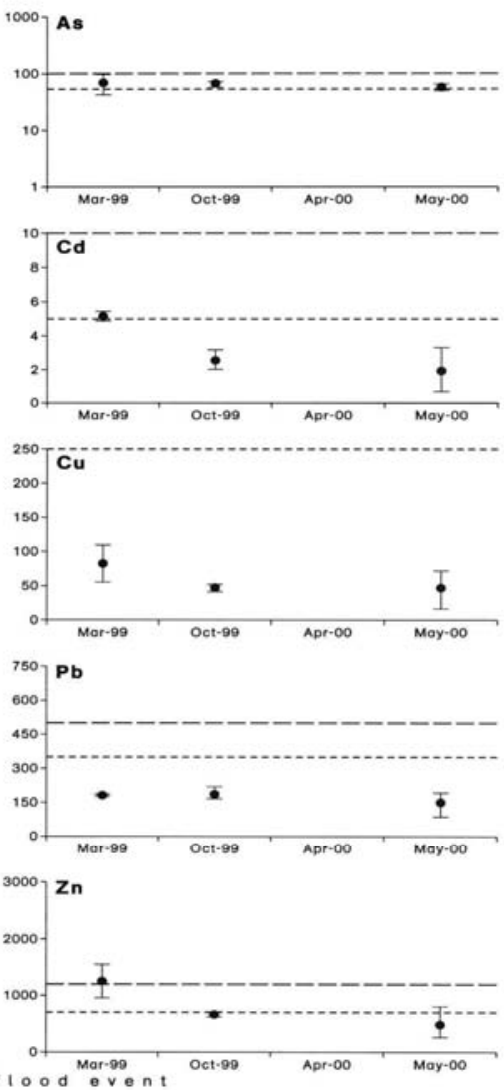

Intervention thresholds

---- Non-sensitive

Figure 6. Heavy metal and As concentrations in overbank sediment deposited during floods in February 1999, October 1999, April 2000 and May 2000.

Doñana Natural Park. Sensitive and non-sensitive intervention thresholds are shown by the long and short dashed horizontal lines, respectively.

Similar to the patterns shown in the valley floor and floodplain geochemical survey (Table 2), all elements show higher concentrations in reach 1 close to the mine, than in the downstream reaches 5 and 6 . Element concentrations in overbank sediments have progressively declined over time, particularly following the first major flood in October 1999, when very high suspended sediment concentrations were recorded. The fall in contaminant concentrations after the October flood could be due to i) further mixing of remobilised contaminated material with "cleaner" sediment ii) removal of contaminated material due to minor clean-up works and/or export to the River Guadalquivir iii) transfer of 
J.N. Turner, P.A. Brewer, M.G. Macklin, K.A. Hudson-Edwards,

T. J. Coulthard, A.J. Howard \& H.E. Jamieson

contaminated material into floodplain and valley floor storage. Our geomorphological surveys show that considerable channel bank erosion and floodplain stripping had occurred at reach 1 and, to a lesser extent, at reach 2 , suggesting that contaminated material is still being sourced from the upper reaches. The net results are that sediments in the lower reaches show no evidence for the delivery of a "front" of contamination, as reported by Ramos et al. (1994) and that element concentrations downstream remain below intervention threshold values. Exceptions, however, are $\mathrm{As}$ and $\mathrm{Pb}$ at reaches 5 and 6 , which have remained almost constant over time.

\section{Conclusions}

Although present day contaminant levels in many parts of the floodplain and valley floor are similar to those before the tailings dam failure, large areas, especially upstream of Sanlúcar Bridge (Figure 1), still have elevated levels of $\mathrm{As}, \mathrm{Cd}, \mathrm{Cu}, \mathrm{Pb}$ and $\mathrm{Zn}$. There are isolated "hotspots" of contamination, which pose a specific problem both in terms of a secondary source of contamination and a potential health hazard to the public. In light of the plans to convert the Guadiamar valley into a municipal "Green Corridor" conservation area (CMA, 2000a), residual raw tailings should be removed. Although some revegetation of the valley floor has taken place, the river is still under-going major channel change, particularly in the upper reaches. Under conditions of channel re-adjustment there continues to be a high risk of contaminant remobilisation.

Under low flows, $\mathrm{Cd}, \mathrm{Cu}$ and $\mathrm{Zn}$, display dissolved concentrations in the upper reaches that exceed EU imperative thresholds for surface water abstraction. On the basis that dilution, through the addition of waters with $\mathrm{pH}>7$, appears to have an ameliorating effect on dissolved heavy metal concentrations, continued controlled discharge from the Agrio reservoir would be advised.

Under high flows, dissolved element concentrations are low, and sediment-associated contaminants dominate heavy metal and As loads. As a consequence, large quantities of remobilised contaminants are moving rapidly downstream, to accumulate in the sedimentation zones of the lower reaches. The implications for this net accumulation is presently offset through the mixing of contaminated and "clean" sediments. As a consequence, there has been a fall in contaminant concentrations in freshly mobilised sediments since the spill and clean-up, which has maintained contaminant levels below regional threshold values in the lower reaches that border the Doñana Natural Park. An exception are As concentrations, which have remained almost constant over time. Given that As also displays anomalously high dissolved concentrations downstream during low flows, the sediment-water interaction of As under predominantly alkaline conditions deserves further consideration. We would also recommend additional research, including an inventory of agricultural inputs (e.g. lead arsenate pesticides) used in the catchment, to determine whether As patterns are linked to an alternative source of As pollution in the Guadiamar.

Declining concentrations in surface sediments throughout the Guadiamar show that the river is recovering. Results from the January 1999 data indicate that if minimum 
flows can be maintained dissolved contaminant concentrations under low flows should remain within guideline limits. Although $\mathrm{CaCO}_{3}$ has been widely employed in the upper reaches of the Guadiamar, in order to raise $\mathrm{pH}$ levels and help fix contaminants to sediments (CMA 2000b), unnecessary floor disturbance has impeded re-vegetation and prolonged geomorphic instability and accelerated erosion. As the upper reaches are the main source of contaminated material in the Guadiamar, we recommend that they are left to recover. In the downstream reaches, declining metal concentrations in surface sediments during the last three years provide a cautiously optimistic outlook for the management of the Doñana nature reserve. In fact, due to the vast quantities of sediment moving through the system, excessive sedimentation could pose a more significant problem than metal pollution in these lower reaches. Conversely, if valley floor vegetation continues to reestablish in the Guadiamar catchment, decreased erosion would lead to a reduction in sediment supply from "cleaner" sources. If sediment mixing is reduced as a result, the present improvements in sediment quality could be reversed.

\section{Acknowledgments}

The authors would like to thank Pavel Adamek and Hugh Blair of Boliden Apirsa s.1. for logistical support and helpful discussions. We would also like to thank the Oficina Técnica for support at reach 6, W Perkins for ICP-MS analysis, V Remenda and S Walker for water sampling and field assistance and the IGES, UW Aberystwyth Graphics Unit for the preparations of diagrams. Funding for this work was provided by NERC (Grant no. GR9/04094, KH-E, MGM), Boliden Apirsa s.l. (MGM, KH-E and HEJ), the Association of Universities and Colleges of Canada (HEJ), and a NERC postgraduate studentship (JNT).

\section{References}

Adriano, D.C., Chlopecka, A., Kaplan, D.I. and Clijsters, H. (1995). Soil contamination and remediation: philosophy, science and technology. Paper presented at the Third International Conference on the biochemistry of trace elements, Paris, France, 15-19 May, 1995. Available on CD ROM.

Almodóvar, G.R., Sáez, R., Pons, J.M., Maestre, A., Toscano, M., Pascual, E. (1998). Geology and genesis of the Aznalcóllar massive sulphide deposits, Iberian Pyrite Belt, Spain. Mineral. Deposita, 33: 111-136.

Benito, G., Benito-Calvo, A., Gallart, F., Martín-Vide, J.P., Regüés, D. and Bladé, E. (2001). Hydrological and geomorphological criteria to evaluate the dispersion risk of waste sludge generated by the Aznalcóllar mine spill (SWSpain). Environ. Geol., 40: 417-428.

Boliden-Apirsa (1999). Generations of Mining: a brief story of the mine and the compa ny (Part One). Boliden Apirsa s.1. 34pp.

CHG (1999). Confederación Hidrográfica del Guadalquivir, unpublished data.

CMA(1999). Memorias de Actuaciones. Report by the Consejería de Medio Ambiente, Government of Andalucía, Spain. Available at: http://www.cma.juntaandalucia.es/guadiamar/indguadiamar.html (access date: 12 December, 2000) 
J.N. Turner, P.A. Brewer, M.G. Macklin, K.A. Hudson-Edwards,

T. J. Coulthard, A.J. Howard \& H.E. Jamieson

CMA (2000a). Programa de Investigación del Corredor Verde del Guadiamar. Report by the Consejería de Medio Ambiente, Government of Andalucía, Spain. Available at: http://www.cma.junta-andalucia.es/guadiamar/picover/picover.html (access date: 12 December, 2000)

CMA (2000b). El Estado de la Contaminación dos años después del Vertido Minero de Aznalcóllar. Report by the Consejería de Medio Ambiente, Government of Andalucía, Spain.

Eriksson N. and Adamek, P. (2000). The tailings pond failure at the Aznalcóllar mine, Spain. Sixth International Symposium in Environmental Issues and Waste Management in Energy and Mineral Production, Calgary, Alberta, Canada, 30 May 2 June 2000.

Gallart, F., Benito, G., Martín Vide, J.P., Benito, A., Prío, J.M. and Regües, D. (1999). Fluvial geomorphology and hydrology in the dispersal and fate of pyrite mud particles released by the Aznalcóllar mine tailings spill. Sci. Total Environ., 242: 13-26.

González-Aurioles, J.M. (1999). Definition of the intervention levels (Law of Wastes 10/1998, of 21 April) for contaminated soil in the Guadiamar River basin (Spain) and the situation of the soil after the removal of the mine tailings. In: Mine Water and Environment, International Congress, International Mine Water Association, September 13-17, 1999, Sevilla, Spain, pp. 247-253.

González, M.J., Fernandez, M., Hernandez, L.M. (1990). Influence of acid mine water in the distribution of heavy metal in soils of Doñana National Park. Application of multivariate analysis. Environ. Technol., 11: 1027-1038.

Graf, W.L. (1994). Plutonium and the Rio Grande: Environmental Change and Contamination in the Nuclear Age. Oxford University Press, New York.

Grimalt, F., Ferrer, M. and Macpherson, E. (1999). The mine tailing accident in Aznalcóllar. Sci. Total Environ., 242: 3-12.

Grimalt, F. and Macpherson, E. (eds.) (1999). The environmental impact of the mine tailing accident in Aznalcóllar (south-west Spain), Sci. Total Environ., 242 (Special Edition).

Hudson-Edwards, K.E., Macklin, M.G., Jamieson, H.E., Brewer, P.A., Coulthard, T.J., Howard, A.J., and Turner, J.N. (in press). The impact of tailings dam spills and cleanup operations on sediment and water quality in river systems: the Ríos AgrioGuadiamar, Aznalcóllar, Spain, Appl Geochem.

Lewin, J. and Macklin, M.G. (1987). Metal mining and floodplain sedimentation in Britain. In, Gardiner, V. (ed) International Geomorphology 1986, Part 1, Wiley, Chichester, pp. 1009-1027.

López-Pamo, E., Barettino, D., Antón-Pacheco, C., Ortiz, G., Arránz, J.C., Gumiel, J.C. and Martínez-Pledel, B. (1999). The extent of the Aznalcóllar pyritic sludge spill and its effect on soils. Sci. Total Environ.. 242: 57-88.

Macklin, M.G. (1996). Fluxes and storage of sediment-associated heavy metals in floodplain systems: assessment and river basin management issues at a time of rapid environmental change. In: Anderson, M.G., Walling, D.E., Bates, P.D. (Eds.), Floodplain Processes, 441-460. John Wiley and Sons, Chichester. 
Macklin, M.G., Hudson-Edwards, K.A., Jamieson, H.E., Brewer, P., Coulthard, T.J., Howard, A.J., Remenda, V.H. (1999). Physical stability and rehabilitation of sustainable aquatic and riparian ecosystems in the Río Guadiamar, Spain, following the Aznalcóllar mine tailings dam failure. In: Mine Water and Environment, International Congress, International Mine Water Association, September 13-17, 1999, Sevilla, Spain, pp. 271-278.

Martín, J.E., García-Tenorio, R., Ontalba-Salamanca, M.Á., Respaldiza, M.A., da Silva, M.F. (2000). TTPIXE analysis of Guardiamar river sediments collected before the environmental disaster of 1998. Nuclear Instruments and Methods in Physics Research B 161-163, 825-829.

McDermott, R.K. and Sibley, J.M. (2000). The Aznalcóllar tailings dam accident - a case study. Miner. Resour. Engineering, 9: 101-118.

Ramos, L., Hernandez, L.M., González, M.J. (1994). Sequential fractionation of copper, lead, cadmium and zinc in soils from or near the Doñana National Park. J. Environ. Qual., 23: 50-57.

Salomons, W. and Förstner, U. (1984). Metals in the Hydrocycle. Springer, Berlin, 349pp.

Sassoon, M. (1998). Los Frailes aftermath. Min. Environ. Manage., 1: 8-12.

Simón, M., Ortiz, I., García, I., Fernández, E., Fernández, J., Dorronsoro, C. and Aguilar, J. (1999). Pollution of soils by the toxic spill of a pyrite mine, Sci. Total Environ., 242: 105-116.

WISE (2001). Chronology of major tailings dams. World Information Service on Energy (WISE) Uranium Project. http://www.antenna.nl/wise/uranium/mdaf.html. 